\title{
Models of evaluating the impact of changes technological and industrial areas in enterprise development
}

\section{Моделі оцінювання впливу змін технологічно-виробничої сфери на розвиток підприсмства}

Received: March 1, $2021 \quad$ Accepted: April 30, 2021

\author{
Written by: \\ Sherstiuk Roman ${ }^{97}$ \\ https://orcid.org/0000-0001-6253-9421 \\ Malevski Eduard ${ }^{98}$ \\ https://orcid.org/0000-0003-0974-4025 \\ Marynenko Nataliia ${ }^{99}$ \\ https://orcid.org/0000-0002-6645-8167 \\ Pavlykivska Olha ${ }^{100}$ \\ https://orcid.org/0000-0003-4104-1733 \\ Melnyk Liliya ${ }^{101}$ \\ https://orcid.org/0000-0001-8844-5490
}

\begin{abstract}
In this paper, the authors demonstrated that the industrial enterprises development is impossible without evaluating changes that occur with technological and manufacturing sector enterprises by external and internal factors. As a result of this study on the ratio of different types of external and internal changes, the authors developed a classification of typical situations in which the technological and production sphere of the enterprise.

To address the evaluation of changes in the paper developed a set of models assessing the impact of natural and artificial changes to enterprise development based on consideration of the consequences of different rates of technological and industrial areas researched the company and its competitors and provides a definition of the type of the current situation in which the industrial an enterprise that provides grounds for the development of appropriate strategies and measures for its development.
\end{abstract}

Keywords: changes, modeling, estimation, development, enterprise, typical situations.

\begin{abstract}
Аннотація
У цій статті авторами доведено, що управління розвитком промислового підприємства неможливо без оцінювання змін, які відбуваються 3 технологічно-виробничою сферою підприємства під впливом зовнішніх та внутрішніх чинників. В результаті цього дослідження за співвідношенням різних типів зовнішніх та внутрішніх змін, авторами розроблено класифікацію типових ситуацій, в яких знаходиться технологічно-виробнича сфера підприємства.

Для вирішення проблеми оцінювання змін, в статті розроблено комплекс моделей оцінювання впливу природних змін та штучних змін на розвиток підприємства, що базується на врахуванні наслідків різних темпів розвитку технологічно-виробничої сфери досліджуваного підприємства та його конкурентів та забезпечує визначення типу поточної ситуації, в якій знаходиться промислове підприємство, що надає підстави для розробки відповідних стратегії та заходів $з$ його розвитку.
\end{abstract}

Ключові слова: зміни, моделювання, оцінка, розвиток, підприємництво, типові ситуації.

\footnotetext{
${ }^{97}$ Doctor of Economics, Head of Department of Management of Innovation Activity and Services Industry, Ternopil Ivan Puluj National Technical University, Ternopil, Ukraine.

${ }^{98}$ Doctor of Economics, Associate Professor of the Department of Economics, European University, Kyiv, Ukraine.

${ }^{99}$ Doctor of Economics, Professor of Economics and Finance Department, Ternopil Ivan Puluj National Technical University, Ternopil, Ukraine.

${ }^{100}$ Doctor of Economics, Head of Department of Accounting \& Taxation, Ternopil Ivan Puluj National Technical University, Ternopil, Ukraine.

101 Doctor of Economics, Associate Professor of the Department of Economics, Ternopil Ivan Puluj National Technical University, Ternopil, Ukraine.
} 


\section{Introduction}

In managing the development of industrial enterprises the main mode of change is changing technological and production sector, as this sector provides the mission of the industrial enterprise - production of modern competitive industrial products. The technologicalproduction sphere is a set of production means, technological equipment, objects of production, technologies of their processing and executors connected in production chains which carry out according to regulations realization of technological processes and operations necessary for performance of mission of the industrial enterprise.

In the operation of the industry as a result of external influences and changes the internal state there are situations that require a response in the form of the management decisions for change technology and industrial sectors. These situations can be caused by both revolutionary and evolutionary changes in the external environment and the natural development of the internal environment of an industrial enterprise, changes phases of its life cycle (Hroznyi et al, 2018).

Implementing changes in the company including sustainable resource management and equitable distribution of benefits and social development - requires acceptance by employees. The implementation of this idea entails the need to implement organizational changes, new technologies and innovative products. Currently, this line of development is beginning to define competitiveness (Tutak, Brodny \& Dobrowolska, 2020).

Ukrainian industrial enterprises differ significantly retarded the development of technological and production sector due to defects typical of post-Soviet companies and savings on investment in innovation. Ukraine is also characterized by the high cost of attracting investment and complexity of finding investors due to political and economic instability. Therefore, management of technological and production areas must take into account the existing dynamics of the economic system, the possibility of industrial enterprises to attract resources to develop and evaluate various options for response situations that require development.

This paper presents a set of models for assessing the impact of natural and artificial changes on enterprise development, able to assess and optimize the implementation of industrial development tasks.

The main idea of the study is that the proposed set of models based on the consequences of different rates of development of technological and production sphere of the studied enterprise and its competitors and provides a definition of the current situation in which the industrial enterprise is located and significantly reduced time.

\section{Theoretical Framework or Literature Review}

The perception of the situation must be interpreted in knowledge as a tool to make the right decision on the adequacy of the changes. In the paper Nathasit Gerdsri et al, (2019) offer a conceptual framework for determining the effects of change on both the internal and external environment.

Yun Fu et al, (2012) predicts the risk of change propagation in terms of change propagation probability and change impact.

Study questions impact assessment on business development of typical situations that require changes in technology and production areas in various aspects performed many scientists, including Changyong et al, (2015) to offer a systematic approach to improve the reliability of planning technology based scripts, adding to assess the impact of future changes on organizational plans. The approach based on a Bayesian network that can examine the uncertainties inherent in future change. They believe that a systematic process and quantitative results, the proposed approach can facilitate operational planning technologies in terms of future uncertainties.

Tarasova et al, (2019) offers industrial enterprises adapt to sudden changes in the external economic environment or changes in the trajectory of enterprises. The disadvantage of the approach is the generality of the proposed recommendations without specifying methods for identifying key areas and quantifying development results.

The purpose of the study (Bril et al, 2021). there is an analysis and development of clear criteria for evaluating the effectiveness of projects and improving management systems. Without denying the prospects of this approach, it should be noted that for the further development and use 


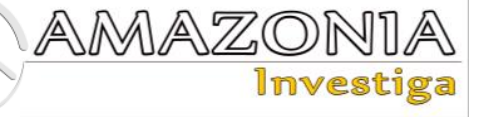

of management practices by industry should be developed methods for determining the condition. In addition, the necessary criteria for evaluating the feasibility and availability changes for improvement.

Some disadvantages of the above approaches is eliminated in the Kwilinski A. (2018), Kwilinski et al, (2019), who developed the evaluation model the effect of measures to modernize production in industrial enterprises, these models make it possible to assess the relationship between the types of activities and competitiveness of enterprises. The peculiarity of the approach is the possibility of adjusting the targets depending on the long-term benchmarks set by the owners of the enterprise. The disadvantage is the difficulty of using the model in real management industry and the inability to build on the basis of calculations made by decision tree based on the availability of resources of different types of businesses.

Custom approach to managing technologymanufacturing sector proposed in the GA and Koposova Shelukhin PG (2012) in which to manage in uncertainty authors developed a system of automatic stabilizers production sector enterprises. This system based on identifying common problems in industrial manufacturing enterprise and building chains destabilizing effects of each of these problems. This ensures speed up decision-making in difficult conditions. But it should be noted that this approach ensures the homeostasis of the system and does not help the decision making for the development of technological and industrial sectors.

Moldavska A. and Welo T. (2019) propose a new CSA (Corporate Sustainability Assessment) method for manufacturing companies in which (1) sustainability is seen as a process of directed change, (2) the assessment tool is developed by modeling a manufacturing company using a system presentation and (3) assessment of corporate resilience (CS). CSA method has a holistic view of sustainable production (SM) and CS (Moldavska \& Welo, 2019).

N. Shmatko (2016) for evaluating the effects of organizational change suggests using a design matrix approach and create a project team to manage the structural and organizational changes.

A review of transformational approaches to resilience shows that they (insufficiently) do not link the processes of change at the micro level with the deep levers of change in the broader structures of the system (Sievers-Glotzbach \& Tschersich, 2019).

Some question the problem of evaluating the situation of industrial enterprises decided to study Juvancir da Silva et al., (2020) where the proposed framework of sustainable development, which contributed to the development and improvement of structured indicators for sustainable development with less analytical ambiguity, duplication and gaps with improved representation of future evaluation efforts (daSilva, etc., 2020).

Müller S. (2016), and Prieger J.E., Bampoky C., Blanco L.R., Liu A. (2016) devoted their research to the progress of entrepreneurship and economic growth of enterprises.

The study focuses on social factors and their impact on enterprise performance (Manzoor, etc., 2020).

The study Choi, S.S., Lee, J.Y. (2017) developed a structure for the integration and management of sustainable enterprise development.

The study (Khudyakova et al, 2020) presents a model of sustainable enterprise development management.

This model provides for close interaction between the mechanisms of strategic decision making and management of investment policy of the enterprise on the basis of the environmental component of business as a factor of sustainable development. Also offered tools that provide interconnection and synergy between the components of strategic management investment company policy and improve the quality of management decisions.

But the main components of this problem remain unresolved.

Thus, the typical drawbacks of traditional approaches to development management of industrial enterprise based on changes in technology and production areas are the lack of structured methods of quantitative impact measurement, forming modernization plan without resources and business opportunities, the lack of a comprehensive assessment of changes and analysis of typical situations caused by the need changes in technology and production in industrial enterprises.

Eliminating this gap in research, we propose a conceptual framework for evaluating the impact 
of changes in natural and artificial changes on enterprise development based on consideration of the consequences of different rates of technological and industrial sectors.

\section{Methodology}

Modern management of industrial enterprise development requires the availability of tools that provide:

classification of typical situations that require changes in technology and production in industrial enterprises, which can be done through the development of appropriate measures for the development of industrial enterprises;

quantitative evaluation of effects of changes in technology and production in industrial enterprises with distribution of the effects of changes without management responses, with minimal effects and consequences reactions after the maximum measures;

implement the conclusions on the importance of management response to changes in technology and production in industrial companies and their distribution according to different criteria of importance in terms of overall development of the industrial enterprise.

It is proposed to distinguish between artificial and natural or internal or external changes in technology and production in industrial enterprises. Artificial changes caused by the interference of the management of its targeted actions to achieve the desired state of the economic system. Natural changes mean changes that occur due to the action of natural forces or due to the influence of factors external to the management system of an industrial enterprise.

For example, to natural changes in technology and production in industrial enterprises include depreciation of fixed assets, falling as a result of the backlog staff development needs, the emergence of new technologies in competition. Depending on whether influenced by changes in the current situation there technologymanufacturing sector industrial enterprises can draw conclusions on whether the situation is controlled and in what degree. The degree of controllability situation is a characteristic that should be considered when deciding on the development of industrial enterprises. It is also proposed to assess the trend of developments in technological and industrial manufacturing sector enterprises, ie whether the current direction changes positive or negative in terms of performance characteristics of commercial enterprises.

The process of evaluating the impact on business development of typical situations that require changes in technology and production sector, consists of the following steps are shown in Figure 1:

analysis artificial changes in technology and production sector;

analysis of natural changes in technology and production sector;

determine the state of technology and production in industrial enterprises. 


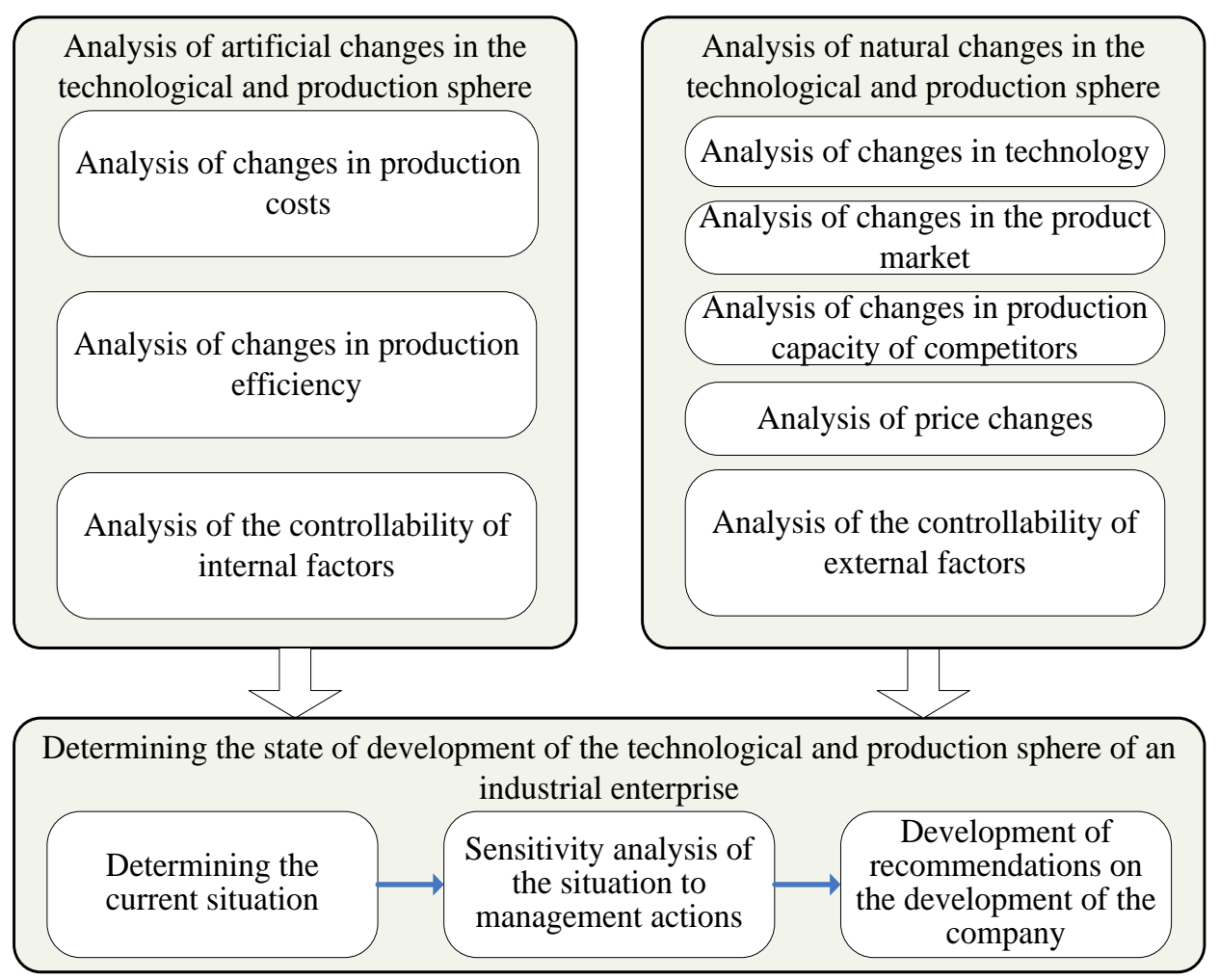

Source: own research.

\section{Figure 1.}

The sequence of assessing the impact on the development of the enterprise of typical situations that require changes in the technological and production sphere.

To determine the degree of controllability of the current situation in the field of technological and industrial manufacturing company proposed to implement a separate analysis of synthetic and natural changes in technology and industrial sectors.

The natural changes that should be evaluated include the presence of all the changes in the external environment, which directly affect the comparative effectiveness of technology and production in industrial enterprises.

Such changes include the following:

the emergence of new modern technologies that have already been mastered by competitors, which affects the competitiveness of enterprise products in price and quality;

appearance on the markets of substitute goods that affect the competitiveness of the range of industrial enterprises;

price fluctuations in the markets of raw materials and finished products produced by an industrial enterprise, which affect the competitiveness of products at price;

change in actual production capacity depending on the wear of equipment and the introduction of new capacity of competitors, which affects the ability of the company to fulfill orders in a timely manner and meet effective demand.

Calculation of changes in modern technologies that use competitors, proposed to implement depending on the importance of production for the company and how much can change the balance of the market introduction of new production technologies of competitors:

$$
\begin{gathered}
\Delta T=1-\sum_{p} F_{p} \frac{W_{p}}{W}, \\
p=1, \ldots, P,
\end{gathered}
$$

where $\Delta T$ - change in production technologies used by competitors of the industrial enterprise;

$W_{p}$ - the volume of sales by the industrial enterprise of the $\mathrm{p}$-th products; 
$W$ - the volume of sales of the industrial enterprise in total;

$F_{p}$ - the coefficient of stability of the market of the $\mathrm{p}$-th industrial products at introduction of new technologies;

$\mathrm{P}$ - the number of products produced by an industrial enterprise.

The coefficient of stability of the market of the pth industrial products at introduction of new technologies depends on a share of competitors in the market and on efficiency of new technologies:

$$
\begin{gathered}
F_{p}=\max \left(0, \frac{V_{p}-\sum_{k}\left(V_{p k} \sum_{n}\left(b_{k n} z_{p n}\right)\right)}{V_{p}}\right) \\
n=1, \ldots, N \\
k=1, \ldots, K,
\end{gathered}
$$

where $F_{p}$ - the coefficient of influence of new technologies on the stability of the market of the p-th industrial products of the enterprise $(0-$ the market becomes completely unstable and completely changes the distribution of market shares between competitors, 1 - the introduction of new technologies by competitors does not change market shares);

$V_{p}$ - market volume of the $\mathrm{p}$-th industrial products;

$V_{p k}$ - the volume of sales of the k-th competitor in the market of the $\mathrm{p}$-th industrial products;

$b_{p k n}$ - whether the $\mathrm{p}$-th competitor uses the n-th new technology in the production of the p-th industrial products $\left(b_{p k n}=0-\right.$ technology is not used, $b_{p k n}=1-$ technology is implemented);

$z_{p n}$ - efficiency of the n-th new technology in the production of the $\mathrm{p}$-th industrial products;

$\mathrm{N}$ - the number of technologies implemented by competitors;

$\mathrm{K}$ - the number of competitors who produce the same products as the industrial enterprise, which is managed.

The closer is an indicator of changes in production technology $\Delta \mathrm{T}$ to unity, the significant changes are natural and therefore lower the degree of controllability of the current situation.
Garbie I.H. (2014) provides an index of sustainable development in manufacturing plants, but it is something else.

Changes due to the appearance on the market substitute products and new products that affect the competitive range of industrial enterprises are invited to count based on the maximum share of the market, which could potentially take substitute products and the importance of industrial enterprise products that can displace from the market products -substitutes.

$$
\begin{gathered}
\Delta S=1-\sum_{p} \frac{W_{p}}{W} \frac{V_{p}}{V_{p}+V_{p}^{S}} \\
p=1, \ldots, P
\end{gathered}
$$

where $\Delta S$ - change due to the appearance on the markets of substitute goods and new goods;

$W_{p}$ - the volume of sales by the industrial enterprise of the $\mathrm{p}$-th products;

$W$ - the volume of sales of the industrial enterprise in total;

$V_{p}-$ market volume of the $\mathrm{p}$-th industrial products;

$V_{p}^{S}$ - the volume of sales of substitute goods for the $\mathrm{p}$-th products of the enterprise;

$\mathrm{P}$ - the number of products produced by an industrial enterprise.

The closer the index is due to changes on the market substitute products and new products $\Delta S$ to unity, the significant changes are natural and therefore lower the degree of controllability of the current situation.

Evaluation situation changes due to fluctuations in the market price of raw materials and finished products proposed to carry out a weighted average value of changes in prices and production costs:

$$
\begin{gathered}
\Delta R=1-\sum_{p} \frac{W_{p}}{W} \frac{\Delta G_{p}}{\Delta C_{p}}, \\
p=1, \ldots, P
\end{gathered}
$$

where $\Delta \mathrm{R}$ - change due to price fluctuations in the markets of raw materials and finished products; 


\section{$\frac{\text { AMAZONDA }}{\text { Dnvestiga }}$}

$W_{p}$ - the volume of sales by the industrial enterprise of the $\mathrm{p}$-th products;

$W$ - the volume of sales of the industrial enterprise in total;

$\Delta G_{p}$ - change in the price of the $\mathrm{p}$-th product;

$\Delta C_{p}-$ change in the cost of $\mathrm{p}$-th products;

$\mathrm{P}$ - the number of products produced by an industrial enterprise.

The closer the figure is the result of changes in market price fluctuations of raw materials and finished products $\Delta \mathrm{R}$ to unity, the material is a negative natural change and therefore lower the degree of controllability of the current situation. Where the figure is zero or is negative, the changes are minor or significant, but positive for the company.

Finally, the change in actual production capacity depending on the wear of equipment and the introduction of new capacity of competitors, which affects the ability of the company to fulfill orders on time and meet effective demand, is calculated as:

$$
\begin{gathered}
\Delta M=\frac{\frac{W}{V} \frac{M^{\prime v}}{M^{\prime u}}}{\sum_{k} \frac{V_{k}}{V} \frac{M_{k}^{\prime v}}{M_{k}^{\prime u}}} \\
k=1, \ldots, K,
\end{gathered}
$$

where $\Delta \mathrm{M}-$ change in actual production capacity;

$W$ - the volume of sales of industrial enterprises;

$V$ - total market capacity of products for all types produced by the industrial enterprise under study;

$V_{k}$ - sales volume of the k-th competitor;

$M^{\prime v}$ - introduction of new production facilities by the enterprise;

$M^{\prime u}$ - disposal of production capacity;

$M_{k}^{v}$ - introduction of new production facilities by the k-th competitor;

$M_{k}^{u}$ - disposal of production capacity of the k-th competitor;
$\mathrm{K}$ - the number of competitors who produce the same products as the industrial enterprise, which is managed.

Indicator value greater than one indicates positive changes at smaller units - negative. The smaller the rate of change of the actual production capacity depending on the wear of equipment and commissioning new facilities $\Delta \mathrm{M}$ rivals the more significant and negative changes are natural and therefore lower the degree of controllability of the current situation.

In turn, artificial changes are changes that occur as a result of management decisions of the company's management.

First of all, these are changes in the technological and production sphere, such as:

introduction of new production technologies;

changes in production capacity, such as acquisition of new equipment or reduction of production capacity;

changes in production processes that are not directly related to production technologies, but change the percentage of shortages, the number of downtimes of equipment and manufacturers, logistics characteristics and other factors that affect production efficiency;

change of qualification of production personnel (can be both positive and negative, has a direct connection with personnel costs);

introduction of other types of products, which differ from the current ones in terms of material consumption, energy consumption, complexity of production, requirements for equipment and qualification of production personnel, etc.

Artificial Internal changes in terms of the analysis of industrial enterprises have expression through changes in the cost of production and due to changes in production efficiency.

Changes in production cost calculated as the ratio of internal factors impact on unit costs to the cost of the unit and taking into account the share of these products in the total output of industrial enterprises:

$$
\begin{gathered}
\Delta C=\sum_{p} \frac{W_{p}}{W} \frac{f_{p}^{C}\left(X_{p}^{C}\right)}{C_{p}}, \\
p=1, \ldots, P
\end{gathered}
$$

where $\Delta \mathrm{C}$ - change in cost due to internal factors; 
$W_{p}$ - the volume of sales by the industrial enterprise of the $\mathrm{p}$-th products;

$W$ - the volume of sales of the industrial enterprise in total;

$f_{p}^{C}\left(X_{p}\right)$ - the cost change function under the influence of many internal factors for the $p$-th product;

$X_{p}-$ set of internal factors that affect the cost of product $\mathrm{p}$-th;

$C_{p}-$ cost of the p-th product;

$\mathrm{P}$ - the number of products produced by an industrial enterprise.

A value of $\Delta \mathrm{C}$ greater than zero indicates positive changes, less than zero - negative. Moreover, if the minimum value of the indicator cannot be less than -1 , then the maximum value is not limited.

Changes in production efficiency are measured as the ratio of changes in time spent on the production of one unit of commodity products (taking into account losses) to the costs of time without changes, taking into account the share of these products in the total output of industrial enterprises:

$$
\begin{gathered}
\Delta M=\sum_{p} \frac{W_{p}}{W} \frac{f_{p}^{M}\left(X_{p}^{M}\right)}{M_{p}}, \\
p=1, \ldots, P,
\end{gathered}
$$

where $\Delta M$ - change in production efficiency due to internal factors;

$W_{p}$ - the volume of sales by the industrial enterprise of the $\mathrm{p}$-th products;
$W$ - the volume of sales of the industrial enterprise in total;

$f_{p}^{M}\left(X_{p}^{M}\right.$ - the function of changing the efficiency of production under the influence of internal factors for set to $\mathrm{p}$-th product;

$X_{p}-$ set of internal factors that affect the efficiency of $\mathrm{p}$-th output;

$M_{p}$ - time for the production of $\mathrm{p}$-th products in the previous period;

$\mathrm{P}$ - the number of products produced by an industrial enterprise.

As for the previous indicator, the value of $\Delta \mathrm{M}$ greater than zero indicates positive changes, less than zero - negative. Moreover, if the minimum value of the indicator cannot be less than -1 , then the maximum value is not limited.

Depending on the type prevalent changes, we can determine the situation for industrial companies and depending on which can be developed management decisions regarding the development of the company.

To determine the type of change, the following gradation is set:

negative - all indicators are negative;

mostly negative - three of the four indicators are negative;

mixed - the distribution of negative and positive indicators is equal;

mostly positive - only one indicator is negative; positive - all indicators are negative.

According to the ratio of different types of external and internal changes, it is proposed to distinguish seven typical situations are shown in Table 1.

Table 1.

\begin{tabular}{|c|c|c|c|c|}
\hline & & \multicolumn{3}{|c|}{ Internal changes } \\
\hline & & Negative & Mixed & Positive \\
\hline \multirow{5}{*}{$\begin{array}{l}\text { External } \\
\text { changes }\end{array}$} & Negative & I & II & II \\
\hline & Mostly negative & I & II & IV \\
\hline & Mixed & III & III & IV \\
\hline & Mostly positive & $\mathrm{V}$ & VI & VI \\
\hline & Positive & $\mathrm{V}$ & VI & VII \\
\hline
\end{tabular}

Types of situations depending on the dynamics of internal and external changes on industrial enterprise.

Source: own research 


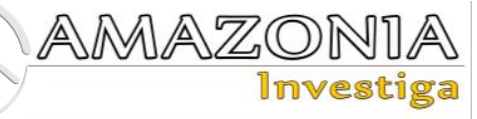

The situation of type I is characterized by the most negative changes in all directions, ie is completely uncontrolled. It requires radical management decisions to overcome the crisis, changes in all areas of activity, because the viability of the enterprise in a situation of type I is under threat.

Type II situations are characterized by moderate control of the internal environment of the industrial enterprise with a simultaneous complex crisis on the part of the external environment. Management should make efforts to improve enterprise adaptability to adverse changes in the environment.

The situation of type III corresponds to the state of enterprises that are under the influence of moderately negative changes, but the quality of management in which is unsatisfactory, because the internal control is low. Out of this situation requires analysis of the origins and development of low controllability of measures to the most critical areas.

In a situation of type IV, the company is also in a negative external environment and has low controllability of external changes, but at the same time excellent internal controllability. Typical actions in this situation is to find methods to carry out an environmental impact or improve measures to improve the adaptability of enterprises.

Favorable external changes occur in situations V type, but internal accountability is entirely unsatisfactory that implicitly indicates poor quality management of industrial enterprise. In the case of industrial enterprises in this situation requires replacement of management or a radical change in strategy.

Mostly positive changes and satisfactory control in all areas characterize the situation of type VI, in which it is necessary to improve only in certain areas of enterprise development.

Finally, the situation type VII meets excellent characteristics for all areas of commercial companies and indicates the need only maintain homeostasis without making radical changes and events.

Based on the results of the analysis of artificial and natural changes in the technological and production sphere and their impact on the controllability of the situation in which the industrial enterprise operates, an analysis of the sensitivity of the situation to managerial influences can be performed. Sensitivity means how much artificial changes in the technological and production sphere will affect the overall controllability of the situation. To do this, it is calculated how the indicator of overall control will change if the company implements development measures with a minimum response to change and with the maximum possible response. Minimal response means using only one's own free resources to improve the situation. The maximum response is to involve all possible resources. A change in the type of situation in which the technological and production sphere of an industrial enterprise is located can be used as a general quantitative assessment of sensitivity. A change of the situation by two or more degrees indicates a significant sensitivity, one degree - a satisfactory sensitivity, the invariability of the situation - the critical importance of environmental influences on the viability of the industrial enterprise.

\section{Results and Discussion}

Approbation of the proposed model was carried out at the machine-building enterprise A. Since the beginning of 2017 the volume of production in real terms decreased continuously is shown in Figure 2. 


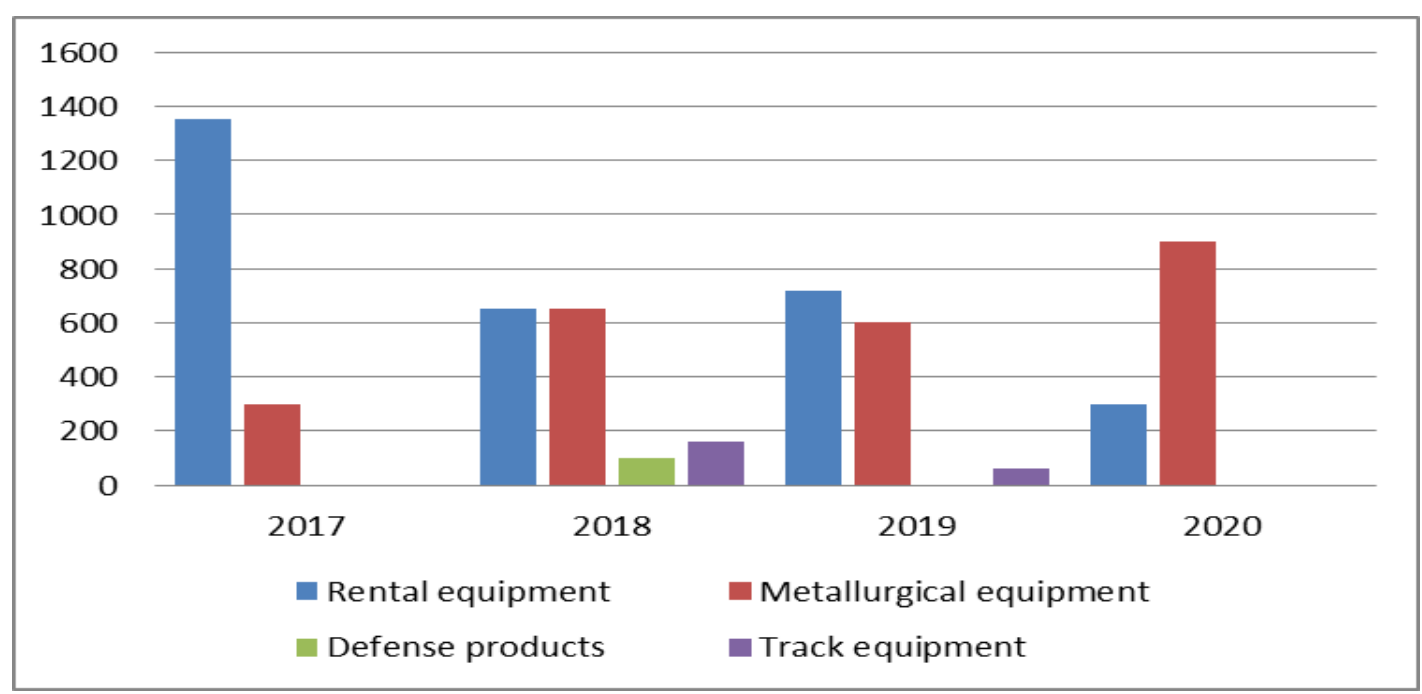

Source: own research.

Figure 2. The volume of production of machine-building enterprise A.

Also unsatisfactory is the dynamics of the ratio of cost to sales, which indicates the unsatisfactory quality of the technological and production sphere. If in 2017 the cost was $77.5 \%$ of the volume of net sales, in 2020 it reached $90 \%$ is shown in Figure 3.

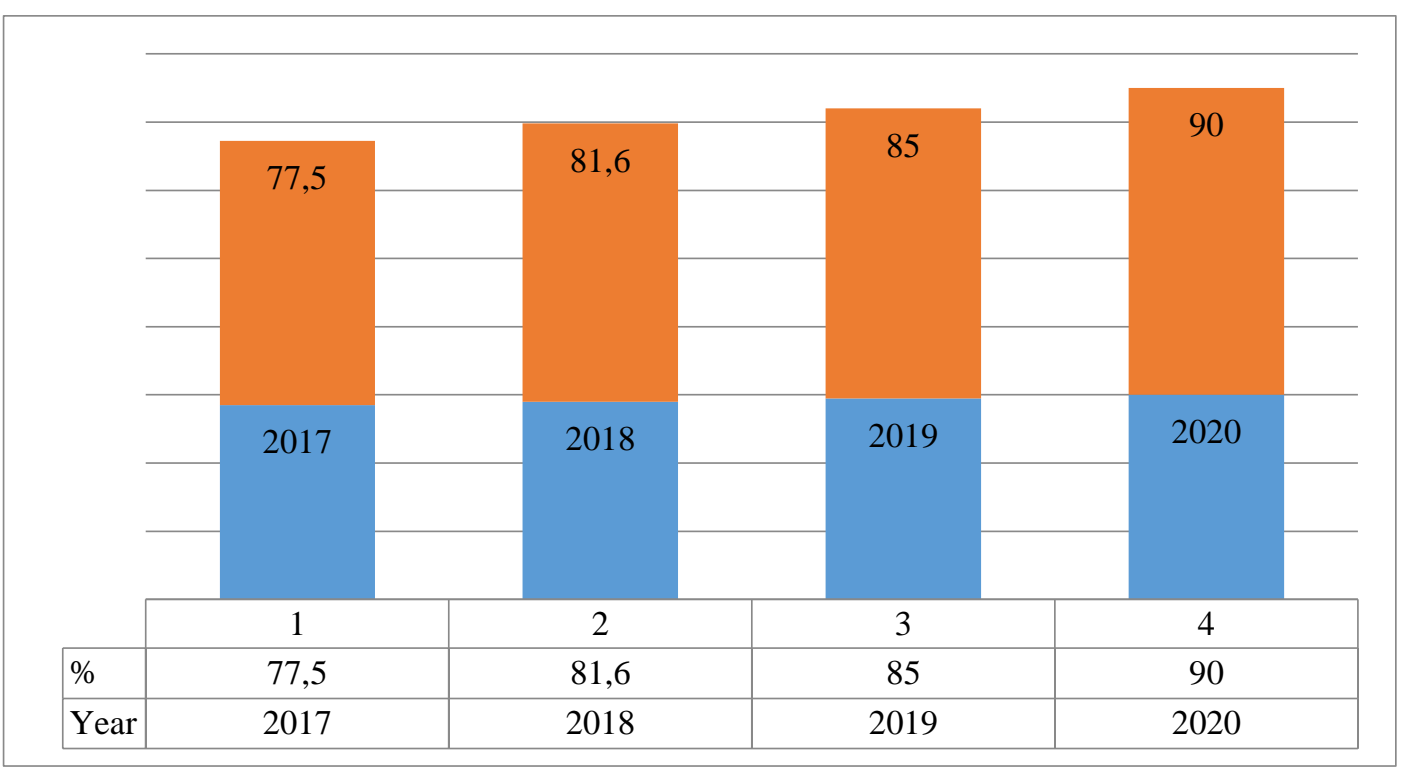

Source: own research.

Figure 3. Dynamics of the share of cost in the amount of net income from the sale of machine - building enterprise A.

According to the results of the inspection of the machine-building enterprise $\mathrm{A}$, it was established that he is in a situation of the third type. Stable are such characteristics as the change in production technologies used by competitors of the industrial enterprise and the change due to the appearance on the markets of substitute goods and new goods. At the same time, the negative change is due to price fluctuations in the markets of raw materials and finished products and change in actual production capacity. Internal changes have a negative trend, changes in cost due to internal factors and changes in production efficiency due to internal factors due to insufficient staff skills, rising costs of wages, equipment wear, etc. are negative.

The main problems of the machine-building enterprise $\mathrm{A}$ in terms of changes in the technological and production sphere are unstable demand in the market of products for metallurgical enterprises, fluctuations in raw 


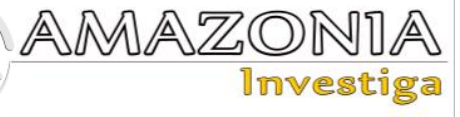

material prices, reduced staff skills, reduced competitiveness of products compared to foreign counterparts. The solution to the above problems is possible due to intensive development, which will block the negative external effects. So, it is proposed to modernize and improve the products manufactured according to modern standards, which will expand the range and quality of products and expand into new markets. In addition, it is important to invest in staff development, especially in the initial training of staff and training.

Thus, through the assessment carried out external and internal environment, impacts, influencing the development of engineering company A and determine the type of situation in which the enterprise is located, was established priorities of technological and industrial sectors.

\section{Conclusions}

The authors of the study argued that modern industrial enterprise development management requires tools that provide: classification of typical situations characterizing technological and production sector industry; quantitative evaluation of effects of changes in technology and production in industrial enterprises; implement the conclusions on the importance of management response to changes in technology and production in industrial companies and their distribution according to different criteria of importance in terms of overall development of the industrial enterprise.

The study proposed to distinguish between artificial and natural or internal or external changes in technology and production in industrial enterprises. Artificial changes caused by the interference of the management of its targeted actions to achieve the desired state of the economic system. Under natural changes implied decimal changes occurring through the action of natural forces or as a result of factors external to the system of industrial enterprise. According to the ratio of different types of external and internal changes, a classification of typical situations in which the technological and production sphere of the enterprise is located has been developed.

Thus, thanks to the developed by the authors of a set of models for assessing the impact of natural and artificial changes on enterprise development, based on the effects of different rates of development of technological and production spheres of the studied enterprise and its competitors, to develop appropriate strategies and measures for development.

As a model assessing the impact of natural changes in enterprise development model presented: calculating changes in modern technologies that use competitors; calculating changes in the markets due to the appearance of substitute products and new products that affect the competitive range of industrial enterprises; calculating the actual production capacity changes depending on the wear of equipment and commissioning of new capacities competition affecting the company's ability to fulfill orders on time and meet effective demand. As a model assessing the impact of artificial change model presented: calculating changes in production costs and calculation of changes in efficiency.

Further development of the proposed approach to assessing the impact of natural and artificial changes on enterprise development will be to refine and expand assessment models with the accumulation of sufficient statistical information, taking into account the peculiarities of the relationship and the environment of industrial enterprises. Expanding and improving the quality of enterprise development, in terms of evaluating and responding to the impact of changes by clarifying the degree of influence inconsistencies and boundary conditions.

\section{Bibliographic references}

Bril, A, Kalinina, O, Valebnikova, O, Valebnikova, N, Camastral, M, Shustov, D, \& Ostrovskaya, N. (2021). Improving Personnel Management by Organizational Projects. Implications for Open Innovation. Journal of Open Innovation: Technology, Market, and Complexity, $7(2), \quad 105$. https://doi.org/10.3390/joitmc7020105

Changyong, L., Song, B. \& Park, Y (2015). An instrument for scenario-based technology roadmapping: How to assess the impacts of future changes on organisational plans. Technological Forecasting and Social Change, 90(A), 285-301, ISSN 0040-1625, https://doi.org/10.1016/j.techfore.2013.12.020.

Choi, S.S. \& Lee, J.Y. (2017). Development of a framework for the integration and management of sustainability for small- and medium-sized enterprises. International Journal of Computer Integrated Manufacturing, 30(11).

Da Silva, J., Fernandes, V., Limont, M. \& Bonino, W. (2020). Sustainable development assessment from a capitals perspective: Analytical structure and indicator selection criteria. Journal of Environmental Management, 
260, 110-147, ISSN 0301-4797, https://doi.org/10.1016/j.jenvman.2020.110147

Fu, Y., Li, M., \& Chen, F. (2012). Impact propagation and risk assessment of requirement changes for software development projects based on design structure matrix, International Journal of Project Management, 30(3), 363-373, ISSN 0263-7863,

https://doi.org/10.1016/j.ijproman.2011.08.004. Garbie, I.H. (2014). An analytical technique to model and assess sustainable development index in manufacturing enterprises. International Journal of Production Research, 52 (16).

Gerdsri, N., Puengrusme, S., Vatanana, R., \& Tansurat, P. (2019) Conceptual framework to assess the impacts of changes on the status of a roadmap. Journal of Engineering and Technology Management, 52, 16-31, ISSN 0923-4748,

https://doi.org/10.1016/j.jengtecman.2017.12.00 1.

Hroznyi, I., Kuzmak, O., Kuzmak, O. \& Rusinova, O. (2018). Modeling management of diversification of foreign economic interactions. Problems and Perspectives in Management, 16(1), $155-165$. https://doi.org/10.21511/ppm.16(1).2018.15

Khudyakova, T, Zhuravlyov, V, Varkova, N, Aliukov, S, Shmidt S, \& Zhuravlyov, N. (2020). Improving Approaches to Strategic Enterprise Management in the Context of Sustainable Development. Sustainability, 12(20), 8375. https://doi.org/10.3390/su12208375

Koposov, G.O., \& Shelukhin, P.G. (2012). Automatic stabilizers of the production sphere of the enterprise. Business Inform, 10, 101-105.

Kwilinski, A. (2018). Model for assessing the effect of measures to modernize the production sphere of an industrial enterprise in accordance with the requirements of the information economy. Black Sea Economic Studies, 33, 83-89.

Kwilinski, A., Dalevska, N., Kravchenko, S., Hroznyi, I., \& Kovalenko, I., (2019). Formation of the entrepreneurship model of e-business in the context of the introduction of information and communication technologies. Journal of Entrepreneurship Education, 22 (Special Issue 1:
Entrepreneurship: Investment and Innovation), 1-7.

Manzoor, H., Ashraf, M., \& Ch., A. (2020). The Influence of Social Factors on Business Performance: A Study of Middle Level Managers of Textile-Based Organizations. Amazonia Investiga, 9(33), 59-67. https://doi.org/10.34069/AI/2020.33.09.7

Moldavska, A. \& Welo, T. (2019). A Holistic approach to corporate sustainability assessment: Incorporating sustainable development goals into sustainable manufacturing performance evaluatio. Journal of Manufacturing Systems, 50, 53-68, ISSN $0278-6125$, https://doi.org/10.1016/j.jmsy.2018.11.004

Müller, S. (2016). A progress review of entrepreneurship and regional development: What are the remaining gaps? European Planning Studies, 24(6), 1133-1158. doi:10.1080/09654313.2016.1154506

Prieger, J.E., Bampoky, C., Blanco, L.R., \& Liu, A. (2016). Economic Growth and the Optimal Level of Entrepreneurship. World Development, 82, 95-109. doi:10.1016/j.worlddev.2016.01.013

Shmatko, N. (2016). Organization of planning structural changes in the process of industrial enterprise development. Development Management, $\mathrm{N}^{\circ} 4,138-143$.

Sievers-Glotzbach, S. \& Tschersich, J. (2019). Overcoming the process-structure divide in conceptions of Social-Ecological Transformation. Assessing the transformative character and impact of change processes, Ecological Economics, 164, 106361, ISSN 09218009 ,

https://doi.org/10.1016/j.ecolecon.2019.106361. Tarasova, H., Zaharov, S., Vereskun, M., \& Kolosok, V. (2019). Preventive anticrisis strategy for development of industrial enterprise. Independent Journal of Management \& Production, $\quad 10(5), \quad 1405-1420$. https://doi.org/10.14807/ijmp.v10i5.890

Tutak, M., Brodny, J., \& Dobrowolska, M. (2020). Assessment of Work Conditions in a Production Enterprise-A Case Study. Sustainability, $\quad$ 12(13), 5390. https://doi.org/10.3390/su12135390 